\title{
Is there a world beyond the Web of Science? Publication practices outside the heartland of academic geography
}

\author{
Nick Schuermans, Bruno Meeus and Filip De Maesschalck \\ Department of Earth and Environmental Sciences \\ Katholieke Universiteit Leuven \\ 3001 Heverlee, Belgium \\ Email: Nick.Schuermans@ees.kuleuven.be
}

\begin{abstract}
Because research on the publication practices of academic geographers has been limited to the quantification of journal articles cited in easily searchable databases such as Thomson Reuters' Web of Science or Elsevier's Scopus, the question remains whether journals that are not indexed by these databases flourish or perish under the increasing pressure to publish in outlets with the highest impact factors. To answer this question, we have compiled a database with the complete bibliographies of all Belgian professors that have been working in Belgium in the field of human geography over the last 40 years. Based on our quantitative analysis of 810 articles published in 304 different journals, we come to the conclusion that human geographers from the Dutchspeaking north of the country are currently publishing more in English-language journals and in journals indexed by the Web of Science than their colleagues in the seventies or the eighties, but less in the Dutch and the French languages and in Belgian geographical journals. In the French-speaking south of the country, this evolution is less pronounced, but still present. Even though we applaud the tendency to publish in English and in Web of Science journals because it increases the academic rigour of scholarly research, we are afraid that it hampers the role of academic geography in geography education and society as a whole.
\end{abstract}

Key words academic publishing, Anglo-American hegemony, Web of Science, journals, bibliometrics, Belgium

Full reference Schuermans, N., Meeus, B., De Maesschalck, F. (2010) Is there a world beyond the Web of Science? Publication practices outside the heartland of academic geography, Area, 24, 4, p. 417-424.

Disclaimer The definitive version of this article is (freely) available at www.blackwell-synergy.com http://onlinelibrary.wiley.com/doi/10.1111/j.1475-4762.2010.00938.x/pdf 


\section{Introduction}

In a contribution to this journal, Ugo Rossi (2008) discussed the careers of young geographers in Continental Europe. He concluded that an increasing number of them should be considered as 'multi-layered academic citizens'. With this term, he referred to the growing contingent of European geographers that is forced to publish, work and conduct research in two or more academic universes. In the context of a globalizing academic world, geographers in continental Europe do not only have to produce theoretical formulations and empirical accounts within their own linguistic and intellectual community, with its own traditions, logics and languages, but also within the broader international context, with English as its lingua franca (Vaiou 2004, 531; Aalbers and Rossi, 2007). This constant mediation between two or more academic universes, Minca $(2000,287)$ believes, is the condition of many Swedish, German, Italian, Spanish or Belgian geographers; "a condition of living in incessant and permanent translation between two or more cultural universes".

Over the last couple of years, Area has published a number of articles on the hegemony of the English language in academic geography and the resulting position of non-native English speakers in the academic division of labour. Most of these publications speak of the challenges that are associated with the multiple frameworks of producing and transferring knowledge that confront geographers who do not have English as their native language (e.g. Aalbers, 2004; Müller, 2007). This paper will contribute to this field by addressing Aalbers and Rossi $(2007,285)$ 's contention that "we still know little about the ways in which social scientists based outside the Anglophone world disseminate their scientific results". Even though the debate about the supposed Anglo-American hegemony in human geography and its potential impact on scholarly traditions in the peripheries of academic geography has been extremely critical, "most of the assertions", Andrés Rodríguez-Pose $(2006,603)$ stresses, "are simply grounded on nothing more than the perceptions of individual authors".

So far, scholars interested in the publication strategies of Continental European geographers have largely limited themselves to the quantification of journal articles cited in easily searchable databases such as Thomson Reuter's Web of Science or Elsevier's Scopus (Short et al. 2001, Paasi 2005, Bosman and de Pater 2006). Such bibliometric studies have demonstrated that the dominance of British and American scholars in the top journals of human geography is waning slowly. In spite of the increasing number of articles written by geographers from the European Mainland and Asia, the proportion of contributions from non-English speaking countries remains relatively small (Short et al., 2001; Rodriguez-Pose, 2006).

It cannot be assumed, however, that 'multi-layered academic citizens' send their articles to high-ranking journals only. In the words of Aalbers and Rossi $(2007,285)$ "they are likely to publish in 'international' outlets, but their publication records and curricula are much more complex and multifaceted than those of their colleagues in the US or the UK". It is problematic, therefore, that our knowledge about the publication spaces outside the most important citation databases is very limited. While a lot of attention has been paid to the declining supremacy of Anglo-American geographers in so-called 'international' outlets, the repercussions of academic globalisation for journals and magazines that are not indexed by Web of Science or Scopus are underresearched (Schmitz, 2003). As such, the question remains whether these publications flourish or perish under the increasing pressure to publish in outlets with the highest impact factors.

To answer this question, we have studied the publication practices of human geographers in Belgium. To do so, we collected the complete bibliographies of all Belgian professors in this field over the last forty years and scanned them for journal articles published between 1975-1977, 1985-1987, 1995-1997 and 2005-2007. For every article written by one of the 48 professors in these intervals, we noted the year of publication, the place of publication ${ }^{1}$, the language of publication, the name of the 
journal and the type of journal. We differentiated between foreign (non-Belgian) journals that are indexed by the Web of Science ${ }^{2}$, foreign journals that are not indexed by the Web of Science, Belgian journals published by a geographical society, Belgian journals published by a teachers' association and other Belgian journals. Because we supposed that it was crucial to distinguish between French and Dutch-speaking academics, we registered the university affiliation of all authors.

In the next section we will use the resulting database with 810 articles published in 304 different journals to look successively at the types of journals, the languages and the countries in which Belgian geography professors have published their academic articles over the last forty years. Before discussing our findings, we have to note that the scope and the depth of our study are limited. Despite the fact that Nederhof (2006) shows that journal articles can represent only a small proportion of the general output of social scientists, and despite the fact that a lot of professors at the French speaking universities stressed that their books, book chapters, working papers and newspaper articles were important as well, we have restricted ourselves to journal articles because their particularities were the easiest to find. Secondly, it has to be remarked that our database only consists of bibliographies of full time professors. Articles of master students, PhD candidates and emeriti have only been analysed if a full time professor working at a Belgian department was mentioned as a co-author.

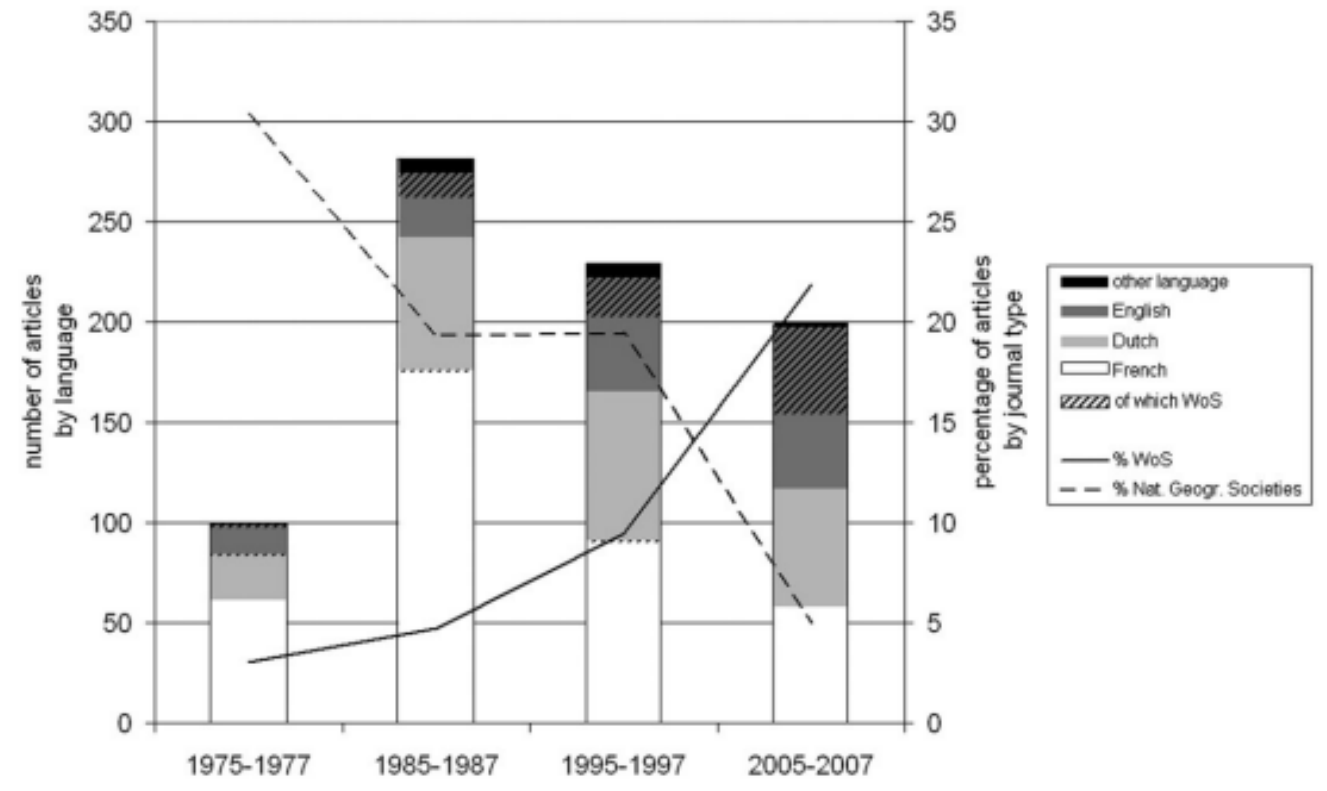

Figure 1 Journal publications of human geographers in Belgium by language and type of journal (1975-2007)

\section{Publication practices in Belgium}

Figure 1 clearly demonstrates that the publication strategies of Belgian academic geographers have changed dramatically over the last forty years. The lines on the graph show that human geographers working in Belgium are currently publishing more in Web of Science journals than ever before. The total percentage of articles indexed by the Web of Science has risen from 5 percent in the seventies to 20 percent in the current decade. At the same time, the amount of articles in journals of the Belgian geographical societies has decreased. Forty years ago, Belgian human geographers published more than 30 percent of their articles in the Belgian Geographical Review (Revue belge de Géographie), the Journal of the Belgian Association of Geographical Studies (published in French as the Bulletin de la Société Belge d'Etudes géographiques and in Dutch as the Tijdschift van de Belgische Vereniging voor Aardrijkskundige Studies) and the Journal of the Geographical Society of Liège 
(Bulletin de la Société géographique de Liège). Now that the Belgian Geographical Review and the Journal of the Belgian Association of Geographical Studies have merged into the Belgian Journal of Geography (Belgeo), the overall share of journals published by the Belgian geographical societies has come down to less than 5 percent.

Table 1 Journal publications of human geographers in Belgium by type of journal

\begin{tabular}{|c|c|c|c|c|c|c|c|}
\hline Dutch-speaking & $\begin{array}{l}\text { Number of } \\
\text { scholars }\end{array}$ & $\begin{array}{l}\text { Foreign } \\
\text { journals } \\
\text { included } \\
\text { in WoS }\end{array}$ & $\begin{array}{l}\text { Foreign } \\
\text { journals } \\
\text { not included } \\
\text { in WoS }\end{array}$ & $\begin{array}{l}\text { Belgian journals } \\
\text { of Belgian } \\
\text { geographical } \\
\text { societies }\end{array}$ & $\begin{array}{l}\text { Belgian } \\
\text { journals } \\
\text { of teachers' } \\
\text { associations }\end{array}$ & $\begin{array}{l}\text { Other } \\
\text { Belgian } \\
\text { journals }\end{array}$ & $\begin{array}{l}\text { Total } \\
\text { output }\end{array}$ \\
\hline $1975-1977$ & 12 & 2 & 3 & 7 & 10 & 15 & 37 \\
\hline $1985-1987$ & 16 & 4 & 30 & 24 & 12 & 47 & 117 \\
\hline $1995-1997$ & 18 & 11 & 28 & 20 & 9 & 60 & 128 \\
\hline $2005-2007$ & 16 & 36 & 47 & 2 & 11 & 57 & 153 \\
\hline \multicolumn{8}{|l|}{ French-speaking } \\
\hline $1975-1977$ & 13 & 1 & 15 & 23 & 0 & 24 & 63 \\
\hline $1985-1987$ & 17 & 9 & 65 & 29 & 3 & 64 & 170 \\
\hline $1995-1997$ & 17 & 10 & 54 & 26 & 0 & 17 & 107 \\
\hline $2005-2007$ & 10 & 8 & 8 & 10 & 2 & 32 & 60 \\
\hline
\end{tabular}

Table I provides a more complete picture of this evolution. Because education and research are regional responsibilities in Belgium (cfr. infra) and because language is one of the most important factors in the creation of geographical spaces of publication, it can be expected that there is a difference between scholars at Dutch and French speaking universities. Even though the interpretation of the table is hampered by the fact that the number of scholars does not remain constant from one decade to another (respectively 12, 16, 18 and 16 in the Dutch speaking universities against 13, 17, 17 and 10 in the French speaking universities), it is obvious that the internationalisation of publication practices is the most pronounced among Dutch speaking academics. Over the last ten years, the total number of Web of Science articles written by scholars working at Dutch speaking universities has more than tripled. Over the same decade, they have increased their total number of publications in journals that are published outside of Belgium but that are not indexed by the Web of Science from 28 to 47 as well.

In sharp contrast to the Flemish geography departments, the French speaking ones have published less abroad between 2005 and 2007 than between 1995 and 1997. In absolute numbers, their total amount of Web of Science articles has gone down from 10 in the third decade to 8 in the last one. Over the same period of time, the number of publications in foreign journals that are not indexed by the Web of Science has decreased from 54 to 8 too. This means that French speaking scholars are currently publishing less abroad than ten or twenty years ago. Only in relative numbers, the share of Web of Science publications has gone up from 2 percent in the seventies to 5 percent in the eighties, 9 percent in the nineties and 13 percent nowadays.

Looking at graph 1, it would seem that the amount of articles published in Belgian journals goes down if the amount of articles published in Web of science journals goes up. From the numbers in table I, it looks as if scholars who send their articles to foreign journals pay less attention to journals that are published by Belgian geographical societies or Belgian teachers' organisations. In the French speaking geography departments, where the international orientation is not so strong, such publications are still very important. While the journal of the French speaking teachers' association (Feuillets de la Fédération des Professeurs de Géographie) has never attracted a lot of contributions from academic geographers, the journals published by the geographical societies and the other Belgian journals take up as much as 17 and 53 percent of the total number of articles published by French speaking human geographers, respectively. 
In the Dutch speaking geography departments, on the other hand, the number of articles in journals of the Belgian geographical societies has dropped dramatically. The absolute number of articles in journals published by one of the Belgian geographical societies has gone down from 24 between 1985 and 1987 to 2 between 2005 and 2007. Over the same period of time, the number of publications in De Aardrijkskunde, a Flemish journal targeted at geography teachers, has remained rather constant, just like the number of articles in other Belgian journals. Proportionally, however, both categories go down as well. For the journals targeted at geography teachers, the main decrease occurred between the seventies and the eighties (from 27 to 7 percent). For the other Belgian journals, it happened in the last decade (from 47 to 37 percent).

The stacked columns in figure 1 show that the internationalisation of Belgian geography is not only evident in the rising number of Web of Science articles and the decreasing number of local articles, but also in the changing languages of publication. Currently, journal articles in English take up about forty percent of the total journal output; articles in Dutch and French both thirty percent. The graph demonstrates that the amount of articles in French has dropped spectacularly after its peak in the eighties and that the number of articles written in Dutch has come down with 20 percent since the nineties. Whereas the popularity of French and Dutch as academic and scientific languages has decreased, the amount of articles in English has increased without interruptions over the last forty years.

Again, it is important to note the differences between Dutch and French speaking geographers. Between 2005 and 2007, professors working at Dutch speaking geography departments have (co-)authored 66 articles in English, 59 in Dutch and 26 in French. Over the same period of time, their colleagues at French speaking universities have published 17 articles in English, 5 in Dutch and 38 in French ${ }^{3}$. While English has become the main language of publication at Dutch speaking universities, French speaking professors have always been writing mostly in French. Obviously, this observation is closely related to the change in publication outlets. While most Web of Science journals do not allow contributions in any language other than English, journals of the Belgian national societies often accept papers in Dutch, French, English and German.

The stacked columns on figure 2 show that the internationalisation of Belgian geography manifests itself in the countries of publication too. The graph indicates that the amount of articles in British and American journals has risen continuously, especially at Dutch speaking universities. Nowadays, more than half of all journal articles written at the Dutch speaking geography departments are published abroad, while this amounts to thirty per cent in the French speaking ones. Between 2005 and 2007, Flemish human geographers published 70 articles in Belgium, 4 in France, 22 in the Netherlands and 45 in the United States and the United Kingdom. Over the same period of time, the French speaking ones published 43 articles in Belgium, 3 in France and 10 in the United States and the United Kingdom.

From a historical perspective, it is interesting to see that the popularity of the journals published in France has fallen spectacularly. This fall explains the decreasing international orientation of the French speaking departments and the declining importance of French as a scientific language among Belgian human geographers. Interestingly enough, it is also clear that the number of articles in Belgian journals has dropped quickly. In French speaking universities, this drop occurred after its peak in the eighties. Dutch speaking universities experienced it a bit later (figure 2).

Such differences between Dutch and French speaking Belgian scholars lead us to expect that research policies, publication cultures and the size of a language community all have a significant impact upon publication strategies. Continuing this line of thought, it has to be assumed that Italian, German or Chinese scholars will have other publication practices. Before concluding our argument, we therefore want to note that we do not anticipate our findings to be automatically transferable to other academic environments in other countries and other language communities. 

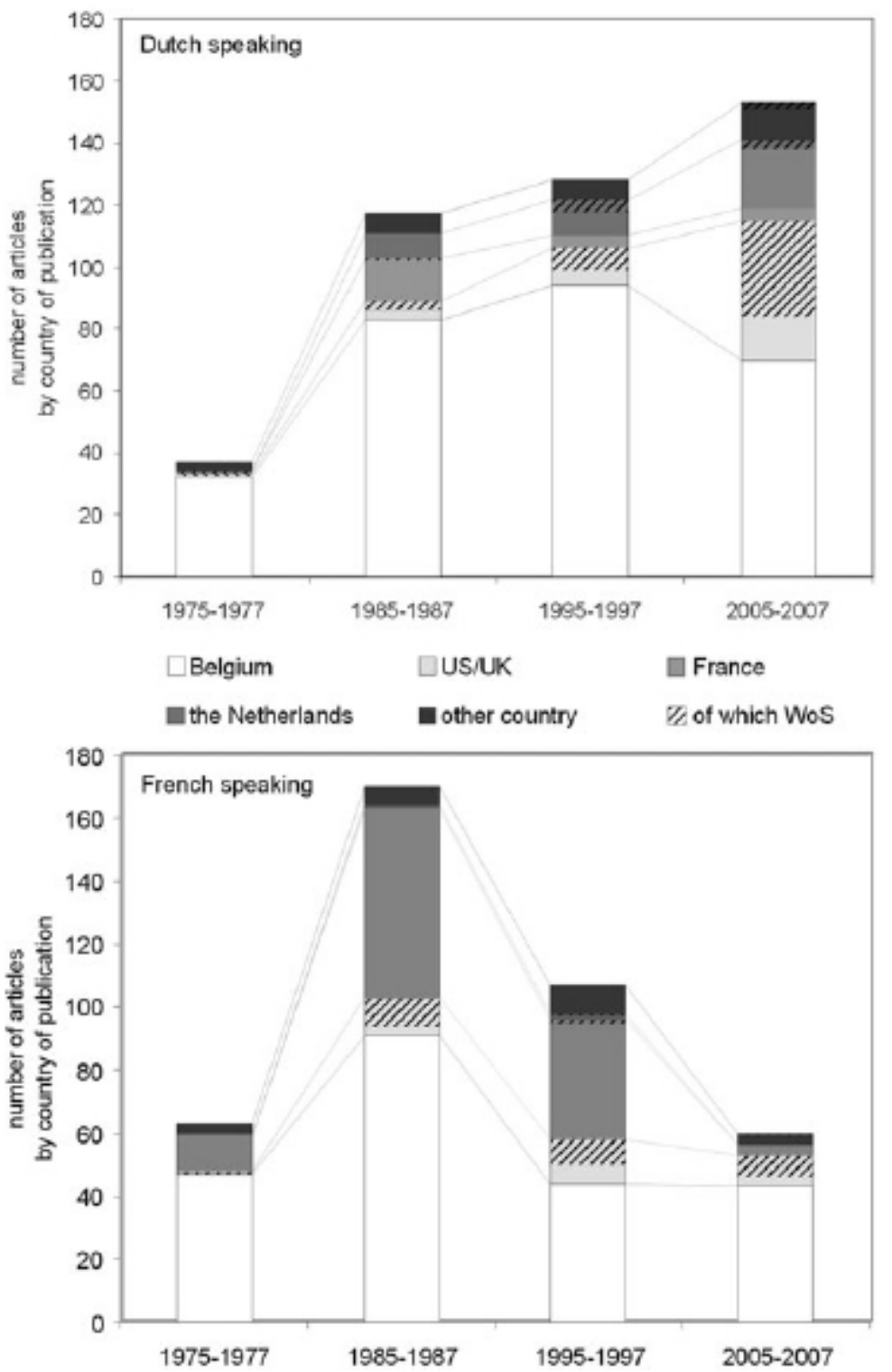

Figure 2 Journal publications of Dutch- and French-speaking human geographers in Belgium by country of publication (1975-2007)

\section{Discussion and conclusion}

One could raise a number of points to explain these developments. In the first place, it has to be acknowledged that every year the Web of Science contains more journals and, thus, more articles, while the number of articles published in journals of the Belgian geographical societies has come down. In addition, it has to be recognized that Belgium does not have a Web of Science journal that focuses explicitly on geographical themes. This means that Belgian geographers need to publish abroad in order to be indexed in the Web of Science, while their colleagues in the Netherlands, Sweden or Austria don't.

We are convinced, however, that the changing publication practices of Belgian geographers can not be understood without referring to the external demands facing them. In Flanders, in particular, publications and citations indexed by the Web of Science have become essential to satisfy funding bodies and university councils. The Belgian constitutional reform of 1988, which gave the Flemish and the French speaking 
communities the possibility to develop their own science policies, was promulgated at a time when the basic allowance of universities was decreasing in real terms. In order to justify their use of public money, Flemish universities were forced by the Flemish Government to set up procedures for a systematic review of the quality of their research activities (Luwel et al 1999). In order to have "objective, quantifiable and repeatable" parameters (Debackere and Glänzel 2004, 253), the Flemish Government turned to bibliometric data, especially in the life sciences and the exact sciences (where most Belgian geography departments are accommodated).

Advocates of this policy are convinced that publications in Web of Science journals are crucial to increase the quality of academic research. Because the peer review procedure of journals with high impact factors is highly selective and because their international readership forces scholars to reflect deeper upon the generalisability, the comparability and the contextuality of their research findings, submitting articles to these journals is said to improve the academic skills of researchers (Walgrave et al. 2008, 181). Advocates of English also assert that it is difficult for academics writing in French, Swedish or Estonian to confront their ideas with a larger and more international audience. For them, the development of a scientific lingua franca seems to be a conditio sine qua non for the creation of a truly international academic community (Short et al., 2001). Because Continental European geographers can only be part of this worldwide community if they make the results of their studies public in journals and languages that are read throughout the world, we are convinced that Belgian, Danish and Spanish geographers should publish their research findings in English, preferably in those journals with the highest impact factors.

Based on our empirical work, we are worried, however, that the internationalisation and the linguistic homogenisation that comes with it do not only raise questions about the potential subtlety and diversity of geographical descriptions and explanations (Short et al. 2001, Hassink 2007), but also about the social responsibilities of academic geography. Because there is a real danger that scholars targeting an international audience do not build up a readership at home (Harris 2001:685), we are afraid that the tendency to publish in English and in Web of Science journals might hamper the role that our discipline plays outside the university. In Flanders, in particular, it is evident that academic geographers who publish mainly in foreign publications do not see a need or do not find the time to write for local journals. Luwel et al. (1999) mention that 'several [Flemish] departments reconsidered and in many cases adapted their publication strategies, avoiding low impact journals as much as they could' because of the growing number of bibliometric assessments with a focus onWeb of Science publications. These bibliometric assessments even 'stimulated discussions about the appropriateness of submitting articles to journals not processed for the SCl' (1999, 136). ${ }^{4}$ From our analysis, it appears that French-speaking human geographers find it easier to publish in their own language and outside theWeb of Science than their Flemish colleagues. In the French-speaking community, the tendency to evaluate the competitiveness of geographers and that of their research departments against their bibliographic records in the world's leading citation databases is less pronounced.

Because an increase in English articles published in high-ranking journals seems to go hand in hand with a decrease in French and Dutch articles written for local outlets, the fact that a lot of local journals struggle to survive has to be connected with the rising pressure to publish in 'international' journals. The Flemish journal targeted at geography teachers might cease to exist in 2010, for example. The Belgian Geographical Review and the Journal of the Belgian Association of Geographical Studies have merged into Belgeo, the Belgian Journal of Geography. This merger provoked a fierce discussion between advocates of 'international' publications and supporters of locally embedded journals (Nicolaï 2004: 36). While the use of English and the global orientation of Belgeo were appreciated by academics interested in a global recognition of their work, other members of the geographical societies feared that the traditional bonds between academic geography and users of its research might 
be weakened. Geography teachers, in particular, complained that they could no longer incorporate articles in their classes because they were written in English and full of academic jargon (Nicolaï 2004: 37).

As such, it has to be recognized that the tendency to publish in English and in academic journals might hamper the intermediary role of science in the society at large. Apart from the fact that such journals deploy an academic English that is not really accessible to teachers, policy makers or social workers, they are also absent in the libraries that they frequent. While an article in a local journal can be read by a lot of people, journals such as 'Area' are only available in university libraries that can afford the steep subscription rates. The fact that a paper in "Brussels Studies", an entirely trilingual journal (French, Dutch and English) that explicitly aims to stimulate the use of scientific articles in public debates, is sometimes downloaded free of charge by more than a thousand people, proves that non-specialised readers are also interested in academic contributions. If Dutch and French speaking professors rarely write articles for such local journals, the integration of scholarly writings into the public debate becomes problematic.

In this context, it is crucial, moreover, that Continental geographers have to show the relevance of their arguments to colleagues in the British and American core of the discipline in order to be accepted by the editors and referees of so-called international journals (Paasi, 2005). Because the boundaries and the rules of the international debate are still marked out in the Anglo-American 'heartland' of academic geography (Minca 2000 287), topics that are considered to be state-of-the-art in Anglo-American geography departments are more likely to be published in high-ranking journals than other issues that might attract more attention in Poland, Belgium or Spain (GarciaRamon 2003, Aalbers and Rossi 2007). As such, the gap between university-level geography and civil society is not only widened because Web of Science journals are written in academic English and because they are difficult to find, but also because researchers from the 'peripheries' of academic geography have to study issues that dominate in the Anglo-American discourse in order to be published (Berg and Kearns 1998, Yeung 2001, Hassink 2007). We could wonder why we study 'ethnic neighbourhoods' and 'gated communities' in Belgium, for instance, while segregation seems to be more problematic at the level of the wider city region (Loopmans et al., forthcoming)? Is it just because we are influenced by Anglo-American debates? Or is it because it is easier to publish about issues that dominate these debates?

Even worse is that the one-sided focus on Web of Science publications might lead to the neglect of some geographical subdisciplines. This would be the case because their research results are more difficult to publish in Web of Science journals, not because they are outdated or irrelevant. When a number of Belgian political scientists asked why none of their colleagues was writing reviews of the Belgian political landscape anymore, the answer was that the research behind it took a lot of time and that it was not specialised and fundamental enough to convert it into Web of Science journals easily (Walgrave et al. 2008, 187-188). The same scholars feared that qualitative research might become less popular because the tables and graphs of quantitative studies are easier to convert into English than interview citations in Dutch or French (Müller 2007, Walgrave et al. 2008, 185).

As young geographers from a small country, we do not want to give the impression that we want to retreat into navel-gazing parochialism. We want to underline, once more, that we applaud the growing inclination of our compatriots to write articles in English and to submit them to journals with high impact factors. Since most of us are paid by taxpayers and not by multinationals that publish Web of Science journals, we are convinced, however, that we have the moral obligation to conduct and publish research that enriches local debates as well (Bonnett 2003; Vaiou 2004). As the overlap between international publications targeted at fellow academics and local journals with a more diverse readership is minimal, we endorse Aalbers' and Rossi's (2007) plea for 'multi-tier spaces of academic publishing'. This does not only mean that scholars 
working in Continental Europe have to address different audiences by writing different articles with different themes in more than one language (as it happens today). It also means that the systems designed to evaluate the performance of academics have to reward more than their bibliographical records in leading citation databases. If funding bodies and university councils do not change their one-sided focus on articles written in English and published in Web of Science journals, it might be feared that academic geographers loose the connection with civil society. Should we only care about the impact factors of our Web of Science articles or also about their impact on society at large: that is the question.

\section{Notes}

1.) Defining the nationality of a publication is not really a straightforward process. If the location of the publisher's office is used, as Paasi (2005) did, the data become distorted because a lot of journals are published by international publishers. While Belgeo is still published in Belgium, the 'Dutch Tijdschrift voor Economische en Sociale Geografie', the Swedish 'Geografiska Annaler' and the British 'Area' are all published by Wiley-Blackwell in the United States, for instance. Because we wanted to respect the particular histories of these journals - histories which are still visible in their editorial boards - we have opted to use the location of the publisher's office to determine the country of publication, unless it was clearly specified on the website of the journal that it was "supported by" or "published on behalf of" another institution.

2.) For the sake of convenience, we have restricted our analysis to the present Web of Science database. If Belgian geographers have published in journals before their backissues were indexed by the database, we might, thus, overestimate the total number of Web of Science articles at a certain moment. Because the number of old Web of Science articles is very low, it is sure that this has not been a very important process, however.

3. Out of the 58 publications in French, 6 have been published in France and the rest in Belgium. Out of the 59 publications in Dutch, 16 have been published in the Netherlands and the rest in Belgium. Most articles in French journals are written in the French language (6 out of 7), and most articles in Dutch journals are in Dutch (only 5 out of 21 are in English).

4. $\mathrm{SCl}$ stands for Science Citation Index. It is part of Thomson Reuters' Web of Science.

Acknowledgements We would like to thank Maarten Loopmans, Isabel Thomas, Mathieu Van Criekingen and two anonymous reviewers for their thought-provoking comments on earlier versions of this paper. We also want to thank all the Belgian geography professors who have sent us their bibliographies. The usual disclaimer applies.

\section{References}

Aalbers M 2004 Creative destruction through the Anglo-American hegemony: a nonAnglo-American view on publications, referees, and language Area 36 319-322

Aalbers M B and Rossi U 2007 A coming community: Young geographers coping with multi-tier spaces of academic publishing across Europe Social \& Cultural Geography 8 283-302

Berg L D and Kearns R A 1998 America Unlimited Environment and Planning D 162 128-132 
Bonnett A 2003 Geography as the world discipline: connecting popular and academic geographical imaginations Area 35 55-63

Bosman J. and de Pater B. 2006 Over centrum en periferie in de sociaal-geografische wetenschappen, met bijzondere aandacht voor de positie van de Vlaamse en Nederlandse geografen in Van Nuffel $\mathbf{N}$ ed Van Christaller tot Wallerstein Nautilius Academic Books, Zelzate 391-412

Debackere K. and Glänzel W. 2004 Using a bibliometric approach to support research policy making: The case of the Flemish BOF-key Scientometrics 592 253-276

Garcia-Ramon M 2003 Globalization and international geography: the questions of languages and scholarly traditions Progress in Human Geography 2711 1-5

Harris C D 2001 English as international language in geography: development and limitations The Geographical Review 914 675-689

Hassink R 2007 It's the language, stupid! On emotions, strategies, and consequences related to the use of one language to describe and explain a diverse world Environment and Planning A 39 1282-1287

Loopmans $\mathbf{M}$, De Decker $\mathbf{P}$, Kesteloot $\mathbf{C}$ forthcoming Social mix and passive revolution; A neo-Gramscian analysis of the social mix rhetoric in Flanders, Belgium Housing Studies

Luwel M, Noyons E C M, Moed, H 1999 Bibliometric assessment of research performance in Flanders: policy background and implications R\&D Management 292 133-141.

Minca, C 2000 Venetian geographical praxis Environment \& Planning D Society \& Space 16 253-256

Müller M 2007 What's in a word? Problematizing translation between languages Area 39 206-213

Nederhof A J 2006 Bibliometric monitoring of research performance in the Social Sciences and the Humanities: A review Scientometrics 66 1 81-100

Nicolai H 2004 Geography in Belgium Belgeo 1 33-44

Paasi A 2005 Globalisation, academic capitalism, and the uneven geographies of international journal publishing spaces Environment and Planning A 37 769-789

Rodriguez-Pose A 2006 is there an 'Anglo-American' domination in human geography? And, is it bad? Environment and Planning A 38, 603-610

Rossi U 2008 Being here and there: in-betweenness, double absence, and the making of a multi-layered academic citizenship Area 40 401-406

Schmitz S 2003 La géographie humaine et ses revues «internationales »: globalisation ou fragmentation? Annales de Géographie 112632 402-411

Short J R Boniche A Kim Y and Li Li P 2001 Cultural globalization, global English, and geography journals Professional Geographer 53 1-11 
Vaiou D 2004 The contested and negotiated dominance of Anglophone geography in Greece Geoforum 35 529-531

Walgrave S Oversloot H and Stouthuysen P 2008 Schrijven is blijven of toch maar publish or perish? Res Publica 50 179-192

Yeung H 2001 Redressing the geographical bias in social science knowledge Environment and Planning A 33 1 1-9 